\title{
The Significance of Including an Entrepreneurship Course in Engineering Programs
}

\author{
Ibrahim Mosly ${ }^{1}$ \\ ${ }^{1}$ Civil Engineering Department, College of Engineering-Rabigh Branch, King Abdulaziz University, Jeddah, \\ Saudi Arabia \\ Correspondence: Ibrahim Mosly, Civil Engineering Department, College of Engineering-Rabigh Branch, King \\ Abdulaziz University, Jeddah, Saudi Arabia. Tel: 966-26-91-1511. E-mail: ibrahim.mosly@hotmail.com
}

Received: August 3, 2017

Accepted: August 14, 2017

Online Published: September 13, 2017

doi:10.5539/hes.v7n4p9

URL: http://doi.org/10.5539/hes.v7n4p9

\begin{abstract}
This paper studied the significance of entrepreneurship education in engineering programs. It looked into its influence on engineering students' perception and willingness to change their future job direction. The study was performed at the College of Engineering-Rabigh Branch, of King Abdulaiziz University in Saudi Arabia. Entrepreneurship education was introduced in 2013 to all of the college's engineering programs in the form of an introductory course on entrepreneurship (IEN 481). This study reveals the importance of entrepreneurship education to engineering students, as the majority of study participants seek to establish their own business in the future. Moreover, $90 \%$ of the participants agreed that the IEN 481 course provided them with sufficient knowledge and skills required to establish their future businesses. In addition, the IEN 481 course changed the students' mindsets and increased their entrepreneurial awareness.
\end{abstract}

Keywords: entrepreneurship education, engineering programs, student perception

\section{Introduction}

Entrepreneurship is defined as self-employment of an individual by practicing business ownership and dealing with important elements, including risk, control, and reward (Kriewall \& Mekemson, 2010). Growth, creativity, and innovation are all part of entrepreneurship (Wilson, 2008; UNCTAD, 2005). Today's world economies are known for high unemployment rates, leading to the important role of developing entrepreneurship and small businesses (Mbuya \& Schachtebeck, 2016). Education can influence the attitudes and objectives of the young; thus, knowing how to develop and foster potential entrepreneurs at school age is important (Wang \& Wong, 2004). This will likely shape the intentions of the young to establish their own enterprise in the future (Wang \& Wong, 2004). Entrepreneurship education provides students with a combination of practical knowledge, skill building, and most prominently, a change in the way of thinking (Wilson, 2008). Changing engineering students' way of thinking is very important because these students usually focus on technical knowledge and lack basic business skills, which they can learn from entrepreneurship education. Students are more likely to consider entrepreneurial careers if they are exposed to entrepreneurship and innovation extensively at the early stages (Wilson, 2008). This includes their undergraduate studies, where they are taught the fundamental skills of their specialization. Entrepreneurship requires a well-established business and regulated environment to succeed (Wilson, 2008). The lack of suitable regulations and environments prevents potential entrepreneurs from establishing their businesses (Wilson, 2008). This means that governments play a major role in the success and development of entrepreneurs in the private sector. Focus on entrepreneurship education has increased among governments, international organizations, and the European Commission (Wilson, 2008). Furthermore, a remarkable increase in entrepreneurship education in universities around the world has been observed over the past few decades (Hamidi et al., 2008). There is a growing movement to incorporate extra entrepreneurial knowledge and skills into engineering education (Duval-Couetil et al., 2016; Rae et al., 2014; Farhangmehr \& Gonçalves, 2016). To align their portfolios with the needs of an emerging knowledge-based economy, entrepreneurship education can assist engineers in developing entrepreneurial and managerial skills (Papayannakis et al., 2008). An entrepreneurial engineer will investigate problems from the traditional perspectives but with a mindset that sees problems as opportunities even if told that the solution is unfeasible (Kriewall \& Mekemson, 2010). Entrepreneurial engineering leads to the design of products and procedures with 
increased value and that generate demand by innovation, leading to positive cash flow, income, and profits (Kriewall \& Mekemson, 2010). An entrepreneurial engineer has the following characteristics: honest, tenacious, ethical, inspired, intuitive, has a sound knowledge of engineering basics, makes products that can be commercialized, has a desire for long-term learning, fits ideas in the context of society, and able to translate their ideas into action/products (Kriewall \& Mekemson, 2010). It is well-recognized that there is a need for engineers with entrepreneurial skills to meet economic and workforce requirements, and thus universities are pressured to graduate students equipped with these types of skills (Duval-Couetil et al., 2010). Currently, more engineering students than before are enrolled in entrepreneurship courses within or external to their engineering programs (Duval-Couetil et al., 2016).

\section{Litrature Review}

\subsection{Entrepreneurship in Engineering Education}

To comprehend and contribute from the perspective of market and business pressure, it is essential for engineers to be entrepreneurial and not just rely on purely technical education (Byers et al., 2013). In addition to entrepreneurial education, engineering students must also be aware of the interaction between technology and the economy (Papayannakis et al., 2008). Through entrepreneurship education, engineering students in different disciplines can obtain the knowledge, tools, and attitudes needed to recognize opportunities and use them in their favor (Byers et al., 2013). Engineering educators are responsible for developing their students' innovation and entrepreneurship skills (Byers et al., 2013). Economic conditions and the realization that all students can create commercial or social value have triggered the shift towards integrating entrepreneurship education into all disciplines, and not only in business (Duval-Couetil et al., 2016). Although entrepreneurship programs and courses in engineering education have developed gradually over the last 20 years, research on entrepreneurship in the scope of engineering education is considered to be in its early phase (Besterfield-sacre et al., 2016). In the United States of America, students lead the considerable and increasing demand for entrepreneurship education (Byers et al., 2013). In the US, entrepreneurship-related courses and programs are very diverse and take several approaches (Duval-Couetil et al., 2016). There are approaches that specifically target engineering students by being embedded within the engineering curriculum, whereas others target students in several majors and are offered across all the campus programs (Duval-Couetil et al., 2016). Programs can also vary according to the objectives required (Duval-Couetil et al., 2016). Certain programs will focus on increasing entrepreneurship concepts, while others will focus on innovation and its aspects (Duval-Couetil et al., 2016). Engineering education communities that consider teaching entrepreneurship a part of their programs are still outside the mainstream (Besterfield-sacre et al., 2016). For the integration of entrepreneurship and innovation in engineering education to be successful, faculty will need to change their viewpoint and be willing to contribute or at least agree to modifications in the engineering curriculum (Byers et al., 2013).

\subsection{Studies Related to the Integration of Entrepreneurship Education in Engineering Programs}

A number of studies worldwide studied the influence of teaching entrepreneurship to engineering students. The majority of these studies reported a positive effect on the student mindset. For example, a study was conducted in two European universities of high standing in science and engineering studies, one in the United Kingdom and the other in France, and showed that entrepreneurship education increased students' entrepreneurial attitudes and aims (Souitaris et al., 2007). A study in the University of Nevada, USA, showed that the addition of a special capstone course that covers entrepreneurship aspects by engaging senior electrical and mechanical engineering students through all phases of product development produced promising results (Wang \& Kleppe, 2001). Students who took the course felt strongly that it should be part of the engineering curriculum (Wang \& Kleppe, 2001). In Sweden, a study that included students with engineering backgrounds studying in a master of entrepreneurship program found that these students had greater intentions of establishing their own businesses in the future (Hamidi et al., 2008). In Singapore, many students wanted to start their own business but felt unprepared to take the risk due to their insufficient business knowledge (Wang \& Wong, 2004). This can be resolved by introducing entrepreneurship educational programs, providing students with training and case studies of successful local entrepreneurial models (Wang \& Wong, 2004). Entrepreneurship education has a significant role in decreasing the unemployment rate in Nigeria (Babatunde \& Durowaiye, 2014). Engineering students were part of a study on engineering education performed in Landmark University, Nigeria (Babatunde \& Durowaiye, 2014). The study confirmed that students exposed to entrepreneurship education had the strong goal of becoming self-employed (Babatunde \& Durowaiye, 2014). This result illustrates the importance of engineering education in creating employment opportunities (Babatunde \& Durowaiye, 2014). A US engineering education study that included engineering students from three universities reported the following suggestions: (1) Multidisciplinary programs could expose engineering students to business concepts; (2) Engineering courses and 
programs should include participation in entrepreneurship activities; and (3) Engineering students should take at least two courses to be capable of conducting entrepreneurial tasks (Duval-Couetil et al., 2016).

\section{Entrepreneurship Course (IEN481) in the College of Engineering-Rabigh Branch, King Abdulaziz University}

The Introduction to Entrepreneurship course IEN 481 is a one-credit course offered in all five engineering programs in the College of Engineering-Rabigh Branch at King Abdulaziz University in Saudi Arabia. The engineering programs are for civil, industrial, electrical, mechanical, and chemical engineering. The IEN 481 course provides students with a summary of the entrepreneurial process from an engineering point of view, including concept creation, planning, financing, marketing, protecting, staffing, leading, growing, and harvesting. Furthermore, students are taught a number of management principles, such as decision-making techniques, planning, marketing, and financial control. The course includes exercises in products or services design as well as prototype development, preparation of feasibility reports, and guidelines for establishing own businesses. Classroom lecture activities include traditional teaching methods and actual case studies, along with guest speakers from the industry. The objectives of the course are:

- Comprehending and explaining entrepreneurial characteristics and skills.

- Business idea selection and evaluation.

- $\quad$ Managing a small- to medium-sized business.

- Applying analytical and critical thinking skills.

The IEN 481 course content includes the following chapters: Entrepreneurs and Entrepreneurship, Dynamics of Business and Economics, Creating Business from Opportunity, Forms of Business Ownership, and Franchising, The Nature of Management, Managing Human Resources, Marketing and Marketing Strategy, Accounting and Financial Management, and Business Plan-Roadmap to Success.

\section{Methodology}

\subsection{Research Background and Objectives}

The motive of this research study began with the introduction of the IEN481 entrepreneurship course in 2013 to all engineering programs in the College of Engineering-Rabigh Branch at King Abdulaiziz University. The study aimed to explore the significance of having such a course in engineering programs and its effect on student perceptions of being an entrepreneur in their field of study. This research is an exploratory study. In exploratory studies, questions are asks to explore what is happening (Greay, 2009). In this research, two questions were asked and both were impact-type research questions. Impact questions work on establishing a casual relationship between variables (Greay, 2009). The following are the research questions of this study:

- Did the entrepreneurship course (IEN 481) change the student's future job direction?

- Did the entrepreneurship course (IEN 481) change the student's perception of being an entrepreneur?

\subsection{Data Collection and Analysis}

In this study, questionnaire surveys were used for data collection. The survey was distributed randomly to engineering students who had completed the IEN 481 course, with the majority being senior and junior students at the College of Engineering-Rabigh Branch, King Abdulaziz University. Data collection took place during May 2017. A total 51 students responded to the questionnaire survey. This sample size is considered very convenient, as approximately 400 students in total were actively enrolled at the college during the survey period. Students from the five engineering programs were asked to participate in the study. The questionnaire survey was designed to be very easy and straightforward. All questions had one answer option, namely "Yes" or "No". The survey consisted of 20 questions categorized into three parts: (1) students' entrepreneurial characteristics and background; (2) students' perception of entrepreneurship and related aspects; and (3) IEN 481 course influence on students and the answers to the research questions. The two main research questions were imbedded among the 20 questions and are presented in Part C. The collected data were analyzed using descriptive statistics in Microsoft Excel 2007 software. Frequency count and simple percentages were conducted for simple data analysis. The selected arrangement of questions and analysis tool helped in answering the research questions.

\section{Results and Discussion}

In general, the feedback received from the 51 students demonstrated a positive influence of the IEN 481 course and a change in their mindsets toward future job directions. The survey questions and student feedback is shown in Table 1. The research results are discussed in this section. For more detail, the three parts of the survey are 
discussed separately in the following subsections on the students' entrepreneurial characteristics and background, students' perception of entrepreneurship and related aspects, and IEN 481 course influence on students and the answers to the research questions.

Table 1. Questionnaire survey and students feedback

\begin{tabular}{|c|c|c|c|c|}
\hline \multirow{2}{*}{ Question } & \multicolumn{2}{|c|}{ Yes } & \multicolumn{2}{|c|}{ No } \\
\hline & Count & $\%$ & Count & $\%$ \\
\hline \multicolumn{5}{|l|}{ A) Students' entrepreneurial characteristics and background } \\
\hline I accept criticism of my work from others. & 45 & 88 & 6 & 12 \\
\hline Do you know how to write a business plan? & 42 & 82 & 9 & 18 \\
\hline Are you a team leader? & 36 & 71 & 15 & 29 \\
\hline Have you entered a competition that requires you to create a new product? & 31 & 61 & 20 & 39 \\
\hline Do you have a mentor that you consider your entrepreneurial idol? & 32 & 63 & 19 & 37 \\
\hline Do you have one or more entrepreneurs in your family? & 30 & 59 & 21 & 41 \\
\hline \multicolumn{5}{|l|}{ B) Students' perception of entrepreneurship and related aspects } \\
\hline Do you plan to establish your own business in the future? & 49 & 96 & 2 & 4 \\
\hline Freedom and independence to be my own boss is very important. & 46 & 90 & 5 & 10 \\
\hline It is important to realize my dreams by working on something that I enjoy. & 46 & 90 & 5 & 10 \\
\hline I consider myself an entrepreneur. & 43 & 84 & 8 & 16 \\
\hline Large financial profits represent a driver for being an entrepreneur. & 43 & 84 & 8 & 16 \\
\hline People around me think that I can start my own business. & 42 & 82 & 9 & 18 \\
\hline I know how to seek funds to start my own business. & 41 & 80 & 10 & 20 \\
\hline The government supports the starting of new businesses. & 40 & 78 & 11 & 22 \\
\hline The financial risk associated with being self-employed is not important to me. & 28 & 55 & 23 & 45 \\
\hline \multicolumn{5}{|l|}{ C) IEN 481 course influence on students and the answers to the research questions } \\
\hline The IEN 481 course provided me with sufficient knowledge and skills required to start my own business. & 46 & 90 & 5 & 10 \\
\hline I believe that knowledge of entrepreneurship is important for engineers. & 45 & 88 & 6 & 12 \\
\hline The IEN 481 course changed my future employment direction. & 45 & 88 & 6 & 12 \\
\hline $\begin{array}{l}\text { The IEN } 481 \text { course changed my perception of my ability to successfully start my own business and } \\
\text { become an entrepreneur. }\end{array}$ & 45 & 88 & 6 & 12 \\
\hline I believe that more entrepreneurship courses should be added to engineering programs. & 40 & 78 & 11 & 22 \\
\hline
\end{tabular}

\subsection{Students' Entrepreneurial Characteristics and Background}

The purpose from this part of the survey was to collect general information on a number of entrepreneurial characteristics and background of the participating students. It consisted of six questions that provided a sense of a student's potential of becoming a successful entrepreneur in the future. For example, students were asked if they would accept criticism of their work from others; $88 \%$ answered "Yes" and $12 \%$ answered "No". The majority of the participants would accept criticism from others, which is essential for the development and improvement of any business. Another question was used to determine whether the students knew how to write a business plan. Most of the students (82\%) answered "Yes" and were confident about writing a business plan. The rest $(18 \%)$, who were not confident about writing a business plan, had covered writing business plans as part of their recently completed IEN 481 course, but it appears that they need to focus more on that topic. An entrepreneur should have certain leadership skills for running their own business, and thus students were asked if they saw themselves as team leaders; 71\% answered "Yes". Furthermore, creating new products or being innovative is part of entrepreneurship, thus students were asked if they were previously engaged in creating new products either in the university or elsewhere; $61 \%$ answered "Yes" while $39 \%$ answered "No". The students 
were also asked if they had a mentor they considered their entrepreneurship idol and if they had one or more entrepreneurs in their families; $63 \%$ and $59 \%$, respectively, answered "Yes", which is a relatively similar proportion. These two questions are significant, as the presence of an entrepreneur mentor and an entrepreneur family member can accelerate and increase the chances of success in the establishment of the student's future business.

\subsection{Students' Perception of Entrepreneurship and Related Aspects}

This section discusses, questions related to the students' perception of entrepreneurship and related aspects. Students were asked if they were interested in establishing their own business in the future, and $96 \%$ answered "Yes"; the high response was unexpected because the majority of Saudi graduates usually choose the safe option of becoming public sector employees. Some of the factors related to the students' intention of establishing their own businesses were freedom and independence, as well as realizing their dreams by working on what they enjoy. Thus, students were asked if freedom and independence to become their own boss were very important; in addition, they were asked if it was important to realize their dreams by working on something they enjoy. The responses for both questions were $90 \%$ "Yes" and 10\% "No". The students were asked a directly: "I consider myself an entrepreneur"; $84 \%$ answered "Yes". At the same time, $84 \%$ answered "Yes" to large financial profits being a driver for becoming entrepreneurs. The majority of students showed confidence in themselves being entrepreneurs and the support from others around them, answering "Yes" (82\%) to the statement "people around me think that I can start my own business". Having the right financial capital is essential for the establishing any business. Thus, entrepreneurs must seek appropriate sources of funds to establish their businesses. In the survey, most of the participants (80\%) answered "Yes" to knowing how to seek funds to establish their businesses. Furthermore, the students acknowledged the government support for entrepreneurs: $78 \%$ answered "Yes" to "The government supports the start of new businesses", while 22\% answered "No". All businesses face financial risks, but risks vary from one business to another. When students were asked about the financial risks associated with being self-employed, 55\% answered "Yes" to these risks being unimportant to them, while $45 \%$ indicated that these risks are important for consideration.

\subsection{IEN 481 Course Influence on Students and the Answers to the Research Questions}

This section focuses on the influence of the IEN 481 course and the entrepreneurship knowledge offered by the college programs to the students, which includes the answers to the earlier research questions. Students were asked about the IEN 481 course content and if it provided them with adequate knowledge and skills to start their own businesses; $90 \%$ answered "Yes" and 10\% answered "No". This shows that the IEN 481 course content is satisfactory but there appear to be some areas for improvement. Moreover, $88 \%$ of the participants believed that knowledge of entrepreneurship is significant for engineers. With regards to the two research questions, $88 \%$ of the participants agreed that the IEN 481 course changed their future employment direction. Also, $88 \%$ of participants agreed that the IEN 481 course changed their perception of becoming entrepreneurs. This validates the importance of the IEN 481 course and its influence on the students. Thus, the addition of an entrepreneurship course into engineering programs has proven very beneficial in changing the students' mindsets as well as allowing them to discover their potential entrepreneurship skills. The majority of students (78\%) believed that more entrepreneurship courses should be added to the available engineering programs. The addition of an extra, advanced entrepreneurship course would cover this need.

\section{Conclusion}

This research investigated the significance of including an entrepreneurship course into engineering programs. The influence of teaching entrepreneurship knowledge and skills to engineering students was validated by the positive impact on their mindset and change in future job direction. The majority of participants showed interest in the subject of entrepreneurship, along with an interest to learn more. Some areas in the college programs can be considered for improvement, such as extra advanced courses on entrepreneurship. This is considered a successful experience and it is recommended that other engineering colleges implement entrepreneurship education in their programs.

\section{References}

Babatunde, E., \& Durowaiye, B. (2014). The Impact of Entrepreneurship Education on Entrepreneurial Intentions among Nigerian Undergraduates. International Journal of Research in Humanities, 2(11), 15-26.

Besterfield-sacre, M., Zappe, S., Shartrand, A., \& Hochstedt, K. (2016). Faculty and Student Perceptions of the Content of Entrepreneurship Courses in Engineering Education. Advances in Engineering Education, 5(1). 
Byers, T., Seelig, T., Sheppard, S., \& Weilerstein, P. (2013). Entrepreneurship Its Role in Engineering Education. In R. Latanision (Ed.), The Bridge. Washington, DC.: National Academy of Engineering.

Duval-Couetil, N., Reed-Rhoads, T., \& Haghighi, S. (2010). Development of an Assessment Instrument to Examine Outcomes of Entrepreneurship Education on Engineering Students. Paper presented at the 40th ASEE/IEEE Frontiers in Education Conference, Washington, DC. https://doi.org/10.1109/FIE.2010.5673411

Duval-Couetil, N., Shartrand, A., \& Reed, T. (2016). The Role of Entrepreneurship Program Models and Experiential Activities on Engineering Student Outcomes. Advances in Engineering Education, 5(1).

Farhangmehr, M., \& Gonçalves, P. (2016). Predicting entrepreneurial motivation among university students: The role of entrepreneurship education. Education+Training, 58(7/8), 861-881. https://doi.org/10.1108/ET-01-2016-0019

Greay, D. (2009). Doing research in the real world. London, UK: SAGE Publications.

Hamidi, D., Wennberg, K., \& Berglund, H. (2008). Creativity in entrepreneurship education. Journal of Small Business and Enterprise Development, 15(2), 304-320. https://doi.org/10.1108/14626000810871691

Kriewall, T., \& Mekemson, K. (2010). Instilling the Entrepreneurial Mindset into Engineering Undergraduates. The Journal of Engineering Entrepreneurship, 1(1), 5-19.

Mbuya, J., \& Schachtebeck, C. (2016). Future entrepreneurs: Does the field of study matter? A comparison of students in a South African urban environment. Problems and Perspectives in Management, 14(2), 228-235.

Papayannakis, L., Kastelli, I., Damigos, D., \& Mavrotas, G. (2008). Fostering entrepreneurship education in engineering curricula in Greece. Experience and challenges for a Technical University. European Journal of Engineering Education, 33(2), 199-210. https://doi.org/10.1080/03043790801980086

Rae, D., Matlay, H., McGowan, P., \& Penaluna, A. (2014). Freedom or prescription: The case for curriculum guidance in enterprise and entrepreneurship education. Industry \& Higher Education, 28(6), 387-398. https://doi.org/10.5367/ihe.2014.0227

Souitaris, V., Zerbinati, S., \& Al-Laham, A. (2007). Do entrepreneurship programmes raise entrepreneurial intention of science and engineering students? The effect of learning, inspiration and resources. Journal of Business Venturing, 22(4), 566-591. https://doi.org/10.1016/j.jbusvent.2006.05.002

UNCTAD. (2005). Entrepreneurship and Economic Development: The Empretec Showcase. Geneva: United Nations Conference on Trade and Development.

Wang, C., \& Wong, P. (2004). Entrepreneurial interest of university students in Singapore. Technovation, 24(2), 163-172. https://doi.org/10.1016/S0166-4972(02)00016-0

Wang, E., \& Kleppe, J. (2001). Teaching invention, innovation, and entrepreneurship in engineering. Journal of Engineering Education, 90(4), 565-570. https://doi.org/10.1002/j.2168-9830.2001.tb00640.x

Wilson, K. (2008). Entrepreneurship education in Europe. In Entrepreneurship and Higher Education (pp. 98-115). Paris, France: OECD.

\section{Copyrights}

Copyright for this article is retained by the author(s), with first publication rights granted to the journal.

This is an open-access article distributed under the terms and conditions of the Creative Commons Attribution license (http://creativecommons.org/licenses/by/4.0/). 